\title{
DISTRIBUTION OF RARE EARTH ELEMENTS IN CORE SEDIMENTS OF KOLAKKUDI LAKE, SOUTHERN INDIA
}

\author{
Radhakrishnan SIVASAMANDY ${ }^{1) *}$, Manavalan SATYANARAYANAN ${ }^{2)}$ \\ and Rangasamy RAMESH ${ }^{3)}$ \\ 1) Centre for Environmental Engineering, PRIST University, Thanjavur, Tamilnadu-613403, India \\ ${ }^{2)}$ HR-ICP-MS Lab CSIR-National Geophysical Research Institute, Hyderabad, India-500007 \\ ${ }^{3)}$ National College, Tiruchirappalli, Tamilnadu-620001, India \\ *Corresponding author's e-mail: sivasamandygeologist@gmail.com
}

\begin{tabular}{l} 
ARTICLE INFO \\
\hline Article history: \\
Received 13 November 2018 \\
Accepted 25 April 2019 \\
Available online 28 November 2019 \\
\hline
\end{tabular}

Keywords:

Kolakkudi Lake

Rare earth elements

Recent sediments

Soils

\begin{abstract}
The lake Kolakkudi represents a small, isolated and fresh water lake situated in southern part of TamilNadu, India and it surrounded by fluvial placer deposits of garnet rich sands. In the study area to obtain information about rare earth elements (REEs) of core sediments and conceded sediment composition and distribution of rare earth elements as well as surrounding soil was investigated. The concentration of REEs in core sediments varies from 0.42 to $49.1 \mathrm{ppm}$. The higher REE content in the core sediments samples from various locations whichsignificance the plethora of clay and/or quartz with less significant effect caused by sedimentary sorting. According to the difference in the levelsof the rare earth elements, the rare earth elements normalized patterns and associated fractionation parameters (SLREE/SHREE, $(\mathrm{La} / \mathrm{Yb}) \mathrm{N}$, and $(\mathrm{NdYb}) \mathrm{N})$ showed similarities between the lake sediments and the surrounding clays, confirming a widespread influence of nearby local lithology on the lake sediment composition. On the other hand, the results of the statistical analysis suggest the contribution of both clay rich soils and garnet rich sands in the lake sediments to the total content of rare earth elements.
\end{abstract}

\section{INTRODUCTION}

Rare earth elements (REEs) comprise a group of 15 chemical elements with similar physical-chemical characteristics (Henderson, 1984). Rare earth elements have been widely used as geochemical indicators in sediments (Haskin et al., 1966). This is an excellent quantitative analytical technique capable of determining 8 REE's (La, Ce, Nd, Sm, Eu, Tb, Yb and $\mathrm{Lu})$ and wide range of concentrations. The lanthanide series are commonly divided into two groups by their atomic number and masses: light REE (LREEs: La$\mathrm{Eu}$ ) and heavy REE (HREEs: Gd-Lu) (Sadeghi et al., 2013; Chen et al., 2014; Wang and Liang, 2016; Silva et al., 2017a) In Addition to our investigations provide information on the distribution of rare earth elements for the lake sediments of Kolakkudi. Some trace elements such as $\mathrm{Sc}, \mathrm{Ga}, \mathrm{Th}, \mathrm{Pb}, \mathrm{Cr}, \mathrm{Zr}, \mathrm{Rb}, \mathrm{Sr}$, and rare earth elements (REEs) are useful indicators of geological processes, provenance, and tectonic settings of sedimentary basins (e.g., Taylor and McLennan, 1985; Jin et al., 2001; Das, 2002; Jin et al., 2003; Das and Haake, 2003; Rose et al., 2004; Armstrong-Altrin et al., 2017, 2018). However, there is still lack of knowledge of REE accumulation in sediments of Kolakkudi lake area where concentration of REEs is likely to be inflated. Rare earth element concentrations in soils are influenced by the mineralogical composition of the parent material, weathering intensity, pedogenic processes, organic carbon and clay contents and anthropogenic activities (Tyler, 2004; Morgan et al., 2012; Anaya-Gregorio et al., 2018; Ramos-Vázquez et al., 2018). The distribution and fractionation patterns of rare earth elements (REE) in sediments relative to those in local source rocks may be related to these factors(Santos et al., 2007). The objectives of this study were as follows: (1) to assess the level of rare earth elements in core sediments of Lake Kolakkudi (2) to get an overview of spatial variations in rare earth elements abundances and fractionation patterns (3) to determine the influence of surrounding geological setting on the distribution of rare earth elements in lake sediments; and (4) to determine the major factors which are controlling the level of these elements in the lake sediments. In this paper we discuss about the geochemical response of rare earth elements to clay rich deposits and garnet rich sands during Kolakkudi lake sediments and their description of the geochemical processes that affecting the distribution of rare earth elements.

\section{TECTONIC SETTING AND REGIONAL GEOLOGY OF STUDIED AREA}

Kolakkudi Lake, located in the Tiruchirappalli district of southern India, is surrounded al soby fluvial placer deposits extending up to $0.60 \mathrm{sq} \mathrm{km}$. The origin of the whole lake especially ephemeral river type of lake. Sediment layers 30 to $45 \mathrm{~cm}$ thickness of clay 


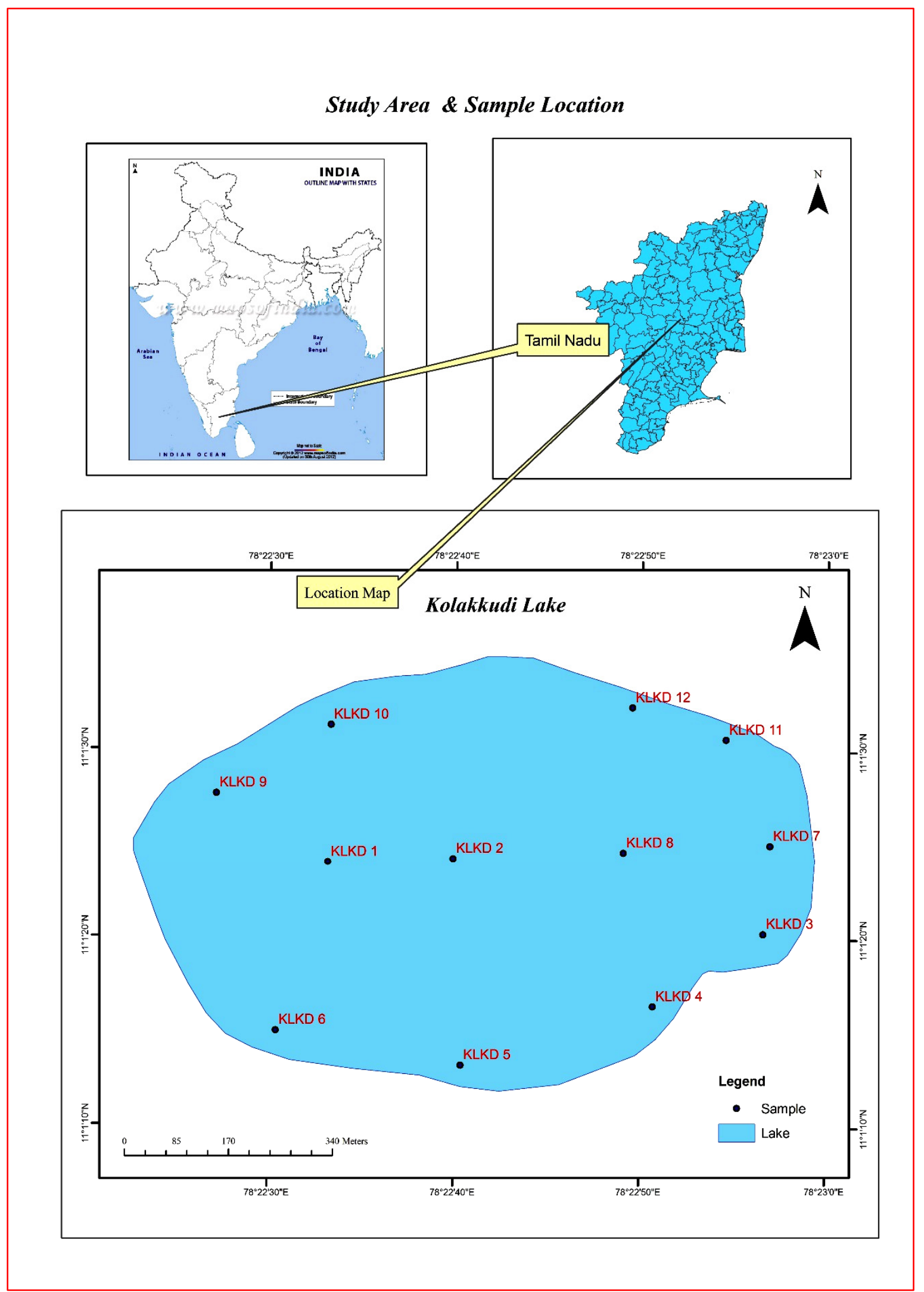

Fig. 1 Location of the study area. 
deposits that recordsof fluvio-lacustrine environment are underlined in this area occupied freshwater lake. The area investigated by Kolakkudilake is part of the peninsular shield granulite terrain in Tamilnadu district of Tiruchirappalli (Fig. 1). The study area is located between North latitudes $11^{\circ} 01^{\prime} 19^{\prime \prime}$ and East longitudes $78^{0} 22^{\prime} 37^{\prime \prime}$ and covered 0.60 sq. $\mathrm{km}$ it forming a part of Musiri taluk the Tiruchirappalli district of Tamilnadu. Geomorphologically, the area northeast of Tiruchchirappalli is in an active erosionstage and illustrates typical topography of the land. Geomorphological units were classified in Tiruchirappalli district based on interpretation of satellite imaging such as Alluvial Plains, Fluvial channels, Valleys, Buried Pediments, shallow Pediments and Structural Hills. The river channels run in to the Tiruchirappalli district's northern bank of Cauvery River. Geologically active, the Kolakkudi Lake, where in the older rocks exposed mostly from sedimentary origin and pegmatite in the deltaic area, and Augen gneiss in the surrounding lake.

\section{MATERIALS AND METHODS}

In October 2013, twelve sediment cores were collected with rotary drill at regular intervals in the Kolakkudi Lake (Fig. 1). Inductively coupled plasma mass spectrometry (ICPMS) itself has analyzed sediment samples of with in the $2 \mathrm{~m}$ core sediments. The core that are used for geochemical analysis was subdivided into one centimeter intervals (upper $10 \mathrm{~cm}$ ) and into Loss on ignition (hereafter assumed to represent the organic matter content-OM) was calculated by burning previously dried sediment at $450{ }^{\circ} \mathrm{C}$ for $24 \mathrm{~h}$, whereas the percentage of finegrained sediment $(0.062 \mathrm{~mm})$ was calculated after mechanical separation through wet sieving (Suguio, 1973).

Sediment samples for REEs, major oxides and trace elements were thoroughly investigated. The samples were air-dried at $501{ }^{\circ} \mathrm{C}$, homogenized and grounded at 200 mesh sizes prior to the geochemical analysis. REEs were measured in twenty sediment samples from the Kolakkudi Lake inlet, central and outlet. After digesting the samples completely with $\mathrm{HF}, \mathrm{HNO}_{3}$ and $\mathrm{HClO}_{4}$ in Teflon crucibles. Before the treatments, these crucibles were properly cleaned with a mixture of $\mathrm{HCl}$ and $\mathrm{HNO}_{3}(3: 1)$. For the digestion, $50 \mathrm{mg}$ of each sample was heated and concurrently treated with $1 \mathrm{ml}$ of $65 \% \mathrm{HNO}_{3}$ for organic carbon removal, with $2 \mathrm{ml}$ of $40 \% \mathrm{HF}$ and $2 \mathrm{ml}$ of $70 \%$ $\mathrm{HClO}_{4}$ to dissolve the silicates. This procedure was followed at least three times till the silica gel showed no more trace of colour. Then the residues also were dissolved with $1 \mathrm{NHCl}$ and the volume was made to $50 \mathrm{ml}$ and measured by HR ICP-MS. For a few samples, total and complete digestions on the carbonate-leached fractions were performed for few samples to determine the effect of carbonates on the mobilityof REE. For the analysis of carbonate leached fractions, bulk samples were treated with $1 \mathrm{M}$ cold dilute $\mathrm{HCl}$ before their digestion as prescribed by Tripathiet al. (1999). REE concentrations in sediment samples were determined by ICP-MS according to the procedures of (Yamamoto et al., 2005).All sediment samples were analyzed for a total concentration of 15 elements Ce, Dy, Er, Eu, Gd, Ho, La, Lu, Nd, Pr, Sm, and $\mathrm{Tb}, \mathrm{Tm}, \mathrm{Yb}, \mathrm{Y})$.

\section{RESULTS}

\subsection{RARE EARTH ELEMENT CONCENTRATIONS}

The rare earth element (REE) concentrations of Kolakkudi Lake sediments were reported in Table 1. All analyzed sediments samples have similar concentrations of the REEs. The REE patterns exhibit variation typical of the average compositions of upper continental crust and Post-Archean Australian average shale (PAAS) and Chinese loess (Gromet et al., 1984; Taylor and McLennan, 1985; Gallet et al., 1996). The REE compositions are normalized to Post Archaean Average Australian Shale (PAAS) and to Upper Continental Crust (UCC) (Taylor and McLennan, 1985) in Figure 2. The PAAS and UCC normalized pattern of bottom sediment show no significant LREE enrichment and exhibit flat HREE patterns. The Eu anomaly in sedimentary rocks were usually interpreted as being inherited from igneous source rocks (McLennan and Taylor, 1991; Taylor and McLennan, 1985; Awwiller, 1993). Figure 2 illustrates that despite the difference in the absolute abundances, the samples show REE patterns that are similar to those of PAAS and UCC but differ in the HREE. Most sediment having slightly higher values than those of PAAS and UCC.

All the REE patterns are characterized by a differentiation between light REE (LREE) and heavy REE (HREE). The differences observed in the REE fractionation may be caused either by chemical weathering processes in the source area or by exchange reactions during transportation and/or deposition. The presence of Positive $\mathrm{Eu}$ anomaly patterns are characteristic features of the mafic source rocks. (Armstrong-Altrin and Machain-Castillo, 2016). Core sediments in the Kolakkudi Lake are characterized by REE concentrations in the range of 2.58 and 8.342 ppm (Table 1). In core sediments, the content of the REE follow the order $\mathrm{Ce}$ $>\mathrm{Nd}>\mathrm{La}>\mathrm{Dy}>\mathrm{Gd}>\mathrm{Sm}>\mathrm{Pr}>\mathrm{Yb}>\mathrm{Er}>\mathrm{Ho}>\mathrm{Eu}>\mathrm{Tb}>\mathrm{Lu}$ and $>$ Tm. The average values of LREE and HREE in core sediments of Kolakkudi Lake sediments are 117.85 and $26.101 \mathrm{ppm}$ respectively. The ratio of LREE/HREE varies from 2.714 to $7.458 \mathrm{ppm}$ which reveals the higher REE content in the core sediments samples from various locations which significance the plethora of clay and/or quartz with less significant effect caused by sedimentary sorting of their results.

The vertical variation in the total REE concentrations ranges along with ratio between LREE/ HREE Vs $\Sigma$ REE are shown in Figures 3A and 3B. It exhibits the relatively high variation. The ratio of light REEs (from La to Sm) to heavy REEs (from Gd to 


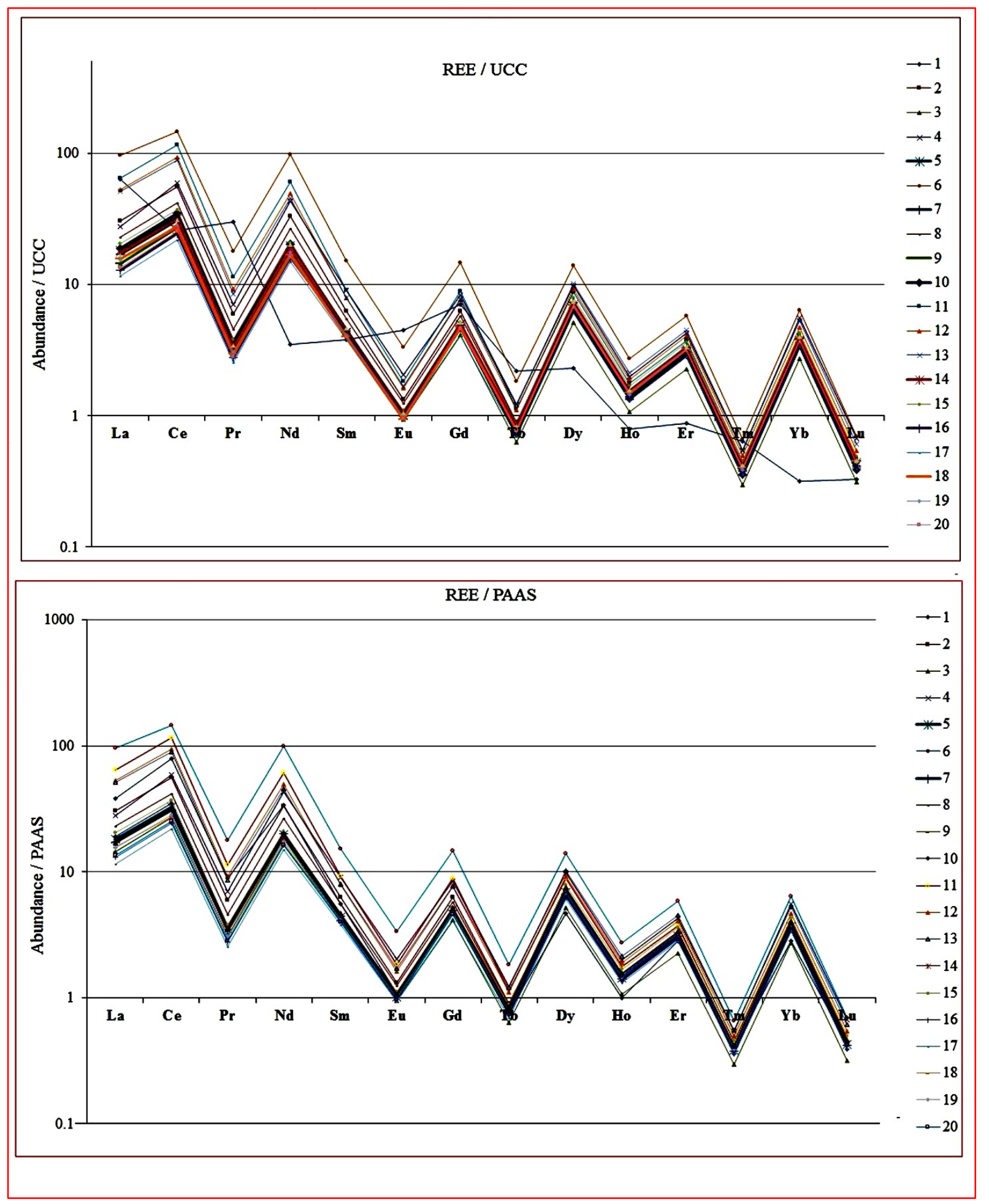

Fig. 2 Plot for normalized values of REE in core sediments of Kolakkudi Lake.

$\mathrm{Lu}$ ), expressed as LREE/HREE, is used to indicate fractionation of total REE between light and heavy REEs. The element ratios of the immobile elements during sedimentation are good indicators of sediment sources (Bhatia and Crook, 1986; Yang et al., 2003; Lee et al., 2003; Tapia-Fernandez et al., 2017 and Hernández-Hinojosa et al., 2018). The core distributions of the $\mathrm{La} / \mathrm{Co}, \mathrm{La} / \mathrm{Sc}, \mathrm{Th} / \mathrm{Sc}$ and $\mathrm{Cr} / \mathrm{Th}$ ratios are shown in Figure 4 A-D. Similar distributional trends in the vertical changes in the REE fractionation parameters in the core were observed which signifying that grain size is dominant controlling factor of the ratios. At all on this basis, REEs are useful for identifying detrital sediment provenance (Munksgaard et al., 2003), monitoring climate change (Tanaka et al., 2007), investigating diagenetic processes (Caetano et al., 2009). The vertical distribution of REE in the base part (30 to $60 \mathrm{~cm}$ ) of the core displays with low to moderate LREE / HREE fractionation (54.77 to 374.74). 
Table 1 Concentration of REE in core sediments of Kolakkudi Lake.

\begin{tabular}{|c|c|c|c|c|c|c|c|c|c|c|c|c|c|c|c|c|c|}
\hline S.No & $\begin{array}{l}\text { Sampling } \\
\text { Stations }\end{array}$ & $\begin{array}{l}\text { Range of } \\
\text { Depth } \\
\text { (in cm) }\end{array}$ & La & $\mathrm{Ce}$ & Pr & Nd & Sm & $\mathbf{E u}$ & Gd & Tb & Dy & Ho & $\mathbf{E r}$ & $\mathbf{T m}$ & $\mathbf{Y b}$ & $\mathbf{L u}$ & $\mathbf{Y}$ \\
\hline 1 & KLKD-1 & $90-120$ & 30.62 & 56.07 & 5.95 & 33.44 & 6.28 & 1.32 & 6.25 & 0.89 & 6.96 & 1.44 & 3.05 & 0.38 & 3.49 & 0.42 & 45.5 \\
\hline 2 & KLKD-2 & $60-90$ & 14.35 & 26.98 & 3.09 & 18.48 & 4.07 & 0.95 & 4.11 & 0.63 & 5.18 & 1.07 & 2.26 & 0.30 & 2.72 & 0.31 & 33.8 \\
\hline 3 & KLKD-3 & $60-90$ & 27.78 & 59.40 & 7.02 & 43.35 & 9.03 & 2.05 & 8.41 & 1.23 & 9.91 & 2.00 & 4.31 & 0.54 & 5.59 & 0.67 & 69.3 \\
\hline 4 & KLKD-4 & $120-150$ & 18.13 & 32.68 & 3.52 & 19.95 & 4.35 & 1.01 & 4.98 & 0.79 & 6.88 & 1.43 & 3.06 & 0.38 & 3.68 & 0.43 & 47.7 \\
\hline 5 & KLKD-5 & $30-60$ & 96.43 & 146.42 & 17.89 & 98.68 & 15.32 & 3.36 & 14.83 & 1.84 & 13.94 & 2.73 & 5.82 & 0.66 & 6.37 & 0.69 & 94.4 \\
\hline 6 & \multirow{2}{*}{ KLKD-6 } & $30-60$ & 17.11 & 31.30 & 3.45 & 20.14 & 4.45 & 1.07 & 4.93 & 0.77 & 6.68 & 1.41 & 3.06 & 0.38 & 3.62 & 0.42 & 45.7 \\
\hline 7 & & $240-270$ & 23.02 & 41.89 & 4.61 & 26.65 & 5.52 & 1.25 & 5.80 & 0.88 & 7.37 & 1.54 & 3.27 & 0.41 & 3.86 & 0.45 & 49.9 \\
\hline 8 & KLKD-7 & $30-60$ & 14.36 & 27.07 & 3.10 & 18.32 & 4.36 & 1.02 & 4.82 & 0.80 & 6.91 & 1.50 & 3.24 & 0.40 & 3.84 & 0.44 & 48.5 \\
\hline 9 & KLKD-8 & $60-90$ & 18.95 & 35.03 & 3.70 & 20.43 & 4.24 & 1.00 & 4.75 & 0.73 & 6.39 & 1.36 & 2.94 & 0.36 & 3.43 & 0.39 & 43.6 \\
\hline 10 & \multirow{2}{*}{ KLKD-9 } & $60-90$ & 64.41 & 115.36 & 11.40 & 61.07 & 9.13 & 1.84 & 8.97 & 1.13 & 8.82 & 1.77 & 3.72 & 0.45 & 4.16 & 0.47 & 57.3 \\
\hline 11 & & $90-120$ & 53.11 & 93.93 & 9.24 & 49.26 & 7.89 & 1.63 & 7.66 & 1.11 & 9.20 & 1.90 & 4.07 & 0.50 & 4.71 & 0.54 & 17.3 \\
\hline 12 & KLKD-10 & $90-120$ & 51.14 & 88.98 & 8.53 & 45.49 & 7.99 & 1.70 & 7.75 & 1.21 & 10.26 & 2.14 & 4.51 & 0.55 & 5.32 & 0.61 & 63.7 \\
\hline 13 & \multirow{3}{*}{ KLKD-11 } & $30-60$ & 17.62 & 31.52 & 3.32 & 19.08 & 4.31 & 1.02 & 4.70 & 0.79 & 7.06 & 1.47 & 3.22 & 0.40 & 3.78 & 0.44 & 71.8 \\
\hline 14 & & $90-120$ & 20.62 & 37.11 & 3.80 & 21.02 & 4.55 & 1.10 & 5.18 & 0.88 & 7.89 & 1.69 & 3.61 & 0.45 & 4.27 & 0.49 & 48.1 \\
\hline 15 & & $150-180$ & 12.95 & 24.46 & 2.76 & 16.35 & 4.27 & 0.99 & 4.76 & 0.83 & 7.31 & 1.55 & 3.31 & 0.41 & 3.89 & 0.45 & 55.1 \\
\hline 16 & \multirow{8}{*}{ KLKD-12 } & $30-60$ & 11.60 & 22.03 & 2.54 & 14.88 & 3.82 & 0.92 & 4.11 & 0.69 & 6.05 & 1.31 & 2.81 & 0.36 & 3.40 & 0.40 & 50.2 \\
\hline 17 & & $90-120$ & 15.77 & 27.66 & 2.96 & 16.91 & 4.03 & 0.94 & 4.72 & 0.78 & 6.91 & 1.49 & 3.25 & 0.40 & 3.95 & 0.45 & 41.5 \\
\hline 18 & & $150-180$ & 15.39 & 28.60 & 3.09 & 17.57 & 4.13 & 0.99 & 4.69 & 0.77 & 6.84 & 1.46 & 3.18 & 0.39 & 3.77 & 0.44 & 48.9 \\
\hline 19 & & $210-240$ & 13.43 & 25.36 & 2.83 & 16.27 & 4.03 & 0.96 & 4.62 & 0.77 & 7.01 & 1.50 & 3.22 & 0.40 & 3.89 & 0.44 & 47.1 \\
\hline 20 & & $240-270$ & 16.92 & 31.38 & 3.47 & 20.05 & 4.65 & 1.06 & 5.19 & 0.84 & 7.42 & 1.58 & 3.34 & 0.42 & 4.01 & 0.46 & 48.5 \\
\hline & & Min & 11.60 & 22.03 & 2.54 & 14.88 & 3.82 & 0.92 & 4.11 & 0.63 & 5.18 & 1.07 & 2.26 & 0.30 & 2.72 & 0.31 & 17.3 \\
\hline & & Max & 96.43 & 146.42 & 17.89 & 98.68 & 15.32 & 3.36 & 14.83 & 1.84 & 13.94 & 2.73 & 5.82 & 0.66 & 6.37 & 0.69 & 94.4 \\
\hline & & Mean & 27.69 & 49.16 & 5.31 & 29.87 & 5.82 & 1.31 & 6.06 & 0.92 & 7.75 & 1.62 & 3.46 & 0.43 & 4.09 & 0.47 & 51.5 \\
\hline
\end{tabular}




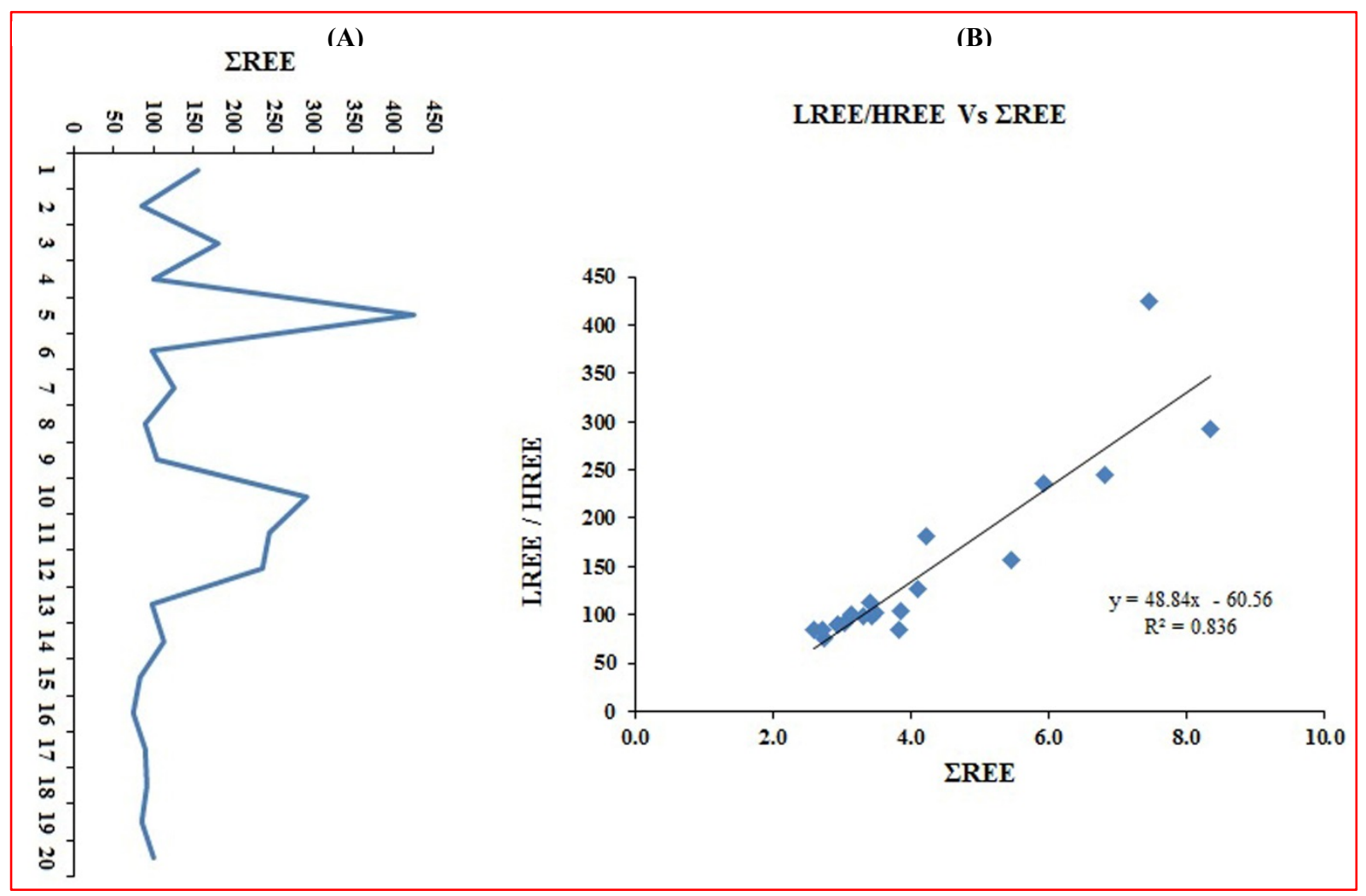

Fig. 3 (A) Vertical Distribution of $\Sigma$ REE.

(B) Diagram of LREE/HREE Vs $\Sigma$ REE.

\subsection{PROVENANCE AND PROCESS OF REE}

There is a significant enrichment of light REE (LREE) over heavy REE (HREE) relative to $\mathrm{La} / \mathrm{Sm}$ ratios ranging from 3.03 to 7.05 with an average 4.38 for core sediments in the Kolakkudi Lake. Here the host rocks/sediments present in this area are interpreted by similar fractionation of LREE from HREE. The Rivers, which debouch into the lake carry through the gneisses and Charnockite formed by retrograde metamorphism in the hinterland followed by laterites and lateritic soils near lake. The REE usually provides a maximum range of trace elements in mineral with similar chemical properties but different mineral homogeneity. This makes them good traces for some geologic processes. In addition, preferential adsorption of LREE's relative to HREEs by clay minerals such as illite, kaolinite, montmorillonite, and chlorite (eg. Cullers et al., 1979) could be an important mechanism. Preferential sorting of heavy minerals such as zircon, sphene, monazite, garnet, allanite, hornblende, feldspar and mica (e.g. Frost et al., 1987) produce REE fractionation in some cases, but which may not hold good here, since our samples represent only the clay fraction. The HREE are concentrated in many heavy minerals of Kolakkudi lake sediments, e.g., zircon and garnet. The variations in $\mathrm{Th}$ and $\mathrm{La}$ indicate the felsic nature of source rock and $\mathrm{Sc}$ and $\mathrm{Co}$ is indicative of mafic source rock. These contents have been used to differentiate between felsic and mafic provenance by various authors (McLennan et al., 1980; Cullers,
2002; Nagarajan et al., 2007a, b; Kasanzu et al., 2008). In this connection, the bivariate diagram can provide information regarding the source rock characteristics. Also, the $\mathrm{Th} / \mathrm{Sc}$ and $\mathrm{La} / \mathrm{Scv}$ alues were suggest a basic source rocks in nature. The high abundance of REE in the sediments is probably due to the relatively high abundances of REE-bearing heavy minerals such as zircon, allanite, sphene, rutile, garnet, etc. (Das et al., 2006).

\section{PROVENANCE OF LAKE SEDIMENTS}

The provenance of the Kolakkudi Lake sediments were interpreted to be a high-grade metamorphic terrain as recorded by the dominance of specific heavy minerals as hornblende, epidote, garnet, chlorite, sillimanite, actinolite, biotite and muscovite. Garnet, a dominant constituent in lake sediments occurring together with Muscovite, sillimanite and epidote, rutile is of high - grade metamorphic origin. The studies of the heavy mineral assemblages have led to infer the dominant role of metamorphic source rocks.

\section{SOURCE ROCK GEOCHEMISTRY}

Trace elemental variations of lake sediments and source rocks of Talamalai hills are reported in Table 2. An enrichment of $\mathrm{Cr}$ and depletion in $\mathrm{Ni}, \mathrm{Sr}$, $\mathrm{Zn}, \mathrm{Co}, \mathrm{Cu}, \mathrm{V}, \mathrm{Zr}$ and $\mathrm{Ba}$ relative abundancies in samples were shown in their studied area (Fig. 5). The variation of high value in $\mathrm{Cr}$ because ilmenite and magnetite minerals are present in the Banded 

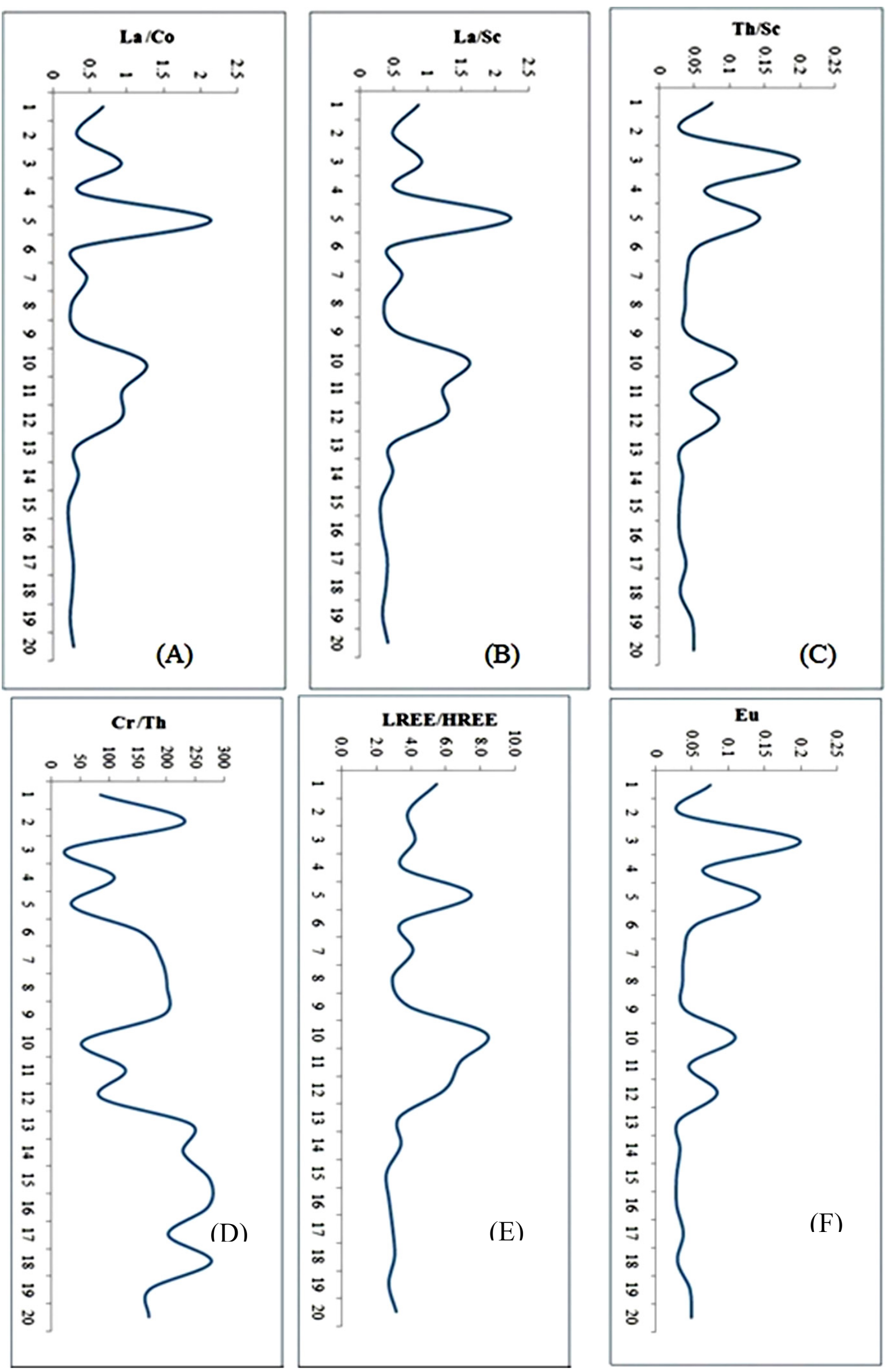

Fig. 4 Fractionation parameter and element ratios in core sediments of Kolakkudi Lake. 
Table 2 Trace elemental variation of Kolakkudi Lake sediments and source rocks.

\begin{tabular}{lccccccccc}
\hline \multicolumn{1}{c}{ Samples } & $\mathbf{B a}$ & $\mathbf{C r}$ & $\mathbf{N i}$ & $\mathbf{S r}$ & $\mathbf{Z n}$ & $\mathbf{C o}$ & $\mathbf{C u}$ & $\mathbf{V}$ & $\mathbf{Z r}$ \\
\hline $\begin{array}{l}\text { Garnetiferous } \\
\text { Gneiss }\end{array}$ & 25.60 & 255.36 & 216.12 & 187.5 & 43 & 25.8 & 11.96 & 85.6 & 437.63 \\
\hline $\begin{array}{l}\text { Garnet Pyroxene } \\
\text { granulite }\end{array}$ & 30.60 & 546.57 & 338.33 & 151.2 & 78.76 & 65.7 & 38.76 & 109.81 & 65.87 \\
\hline Pegmatite & 204.70 & 533.08 & 336.28 & 25.4 & 30.77 & BDL & 12.68 & BDL & 105.16 \\
\hline $\begin{array}{l}\text { Lake sediments } \\
\text { Kolakkudi) }\end{array}$ & 139.08 & 275.84 & 97.56 & 235.47 & 627.37 & 52.7 & 179.77 & 223.24 & 211.18 \\
\hline PAAS & 65.00 & 110.00 & 55.00 & 200.0 & 85.00 & 23.0 & 50.00 & 150.0 & 210.00 \\
\hline UCC & 550.00 & 35.00 & 20.00 & 350.0 & 71.00 & 10.0 & 25.00 & 60.00 & 190.00 \\
\hline & & & BDL-Below Detection Limit & & &
\end{tabular}

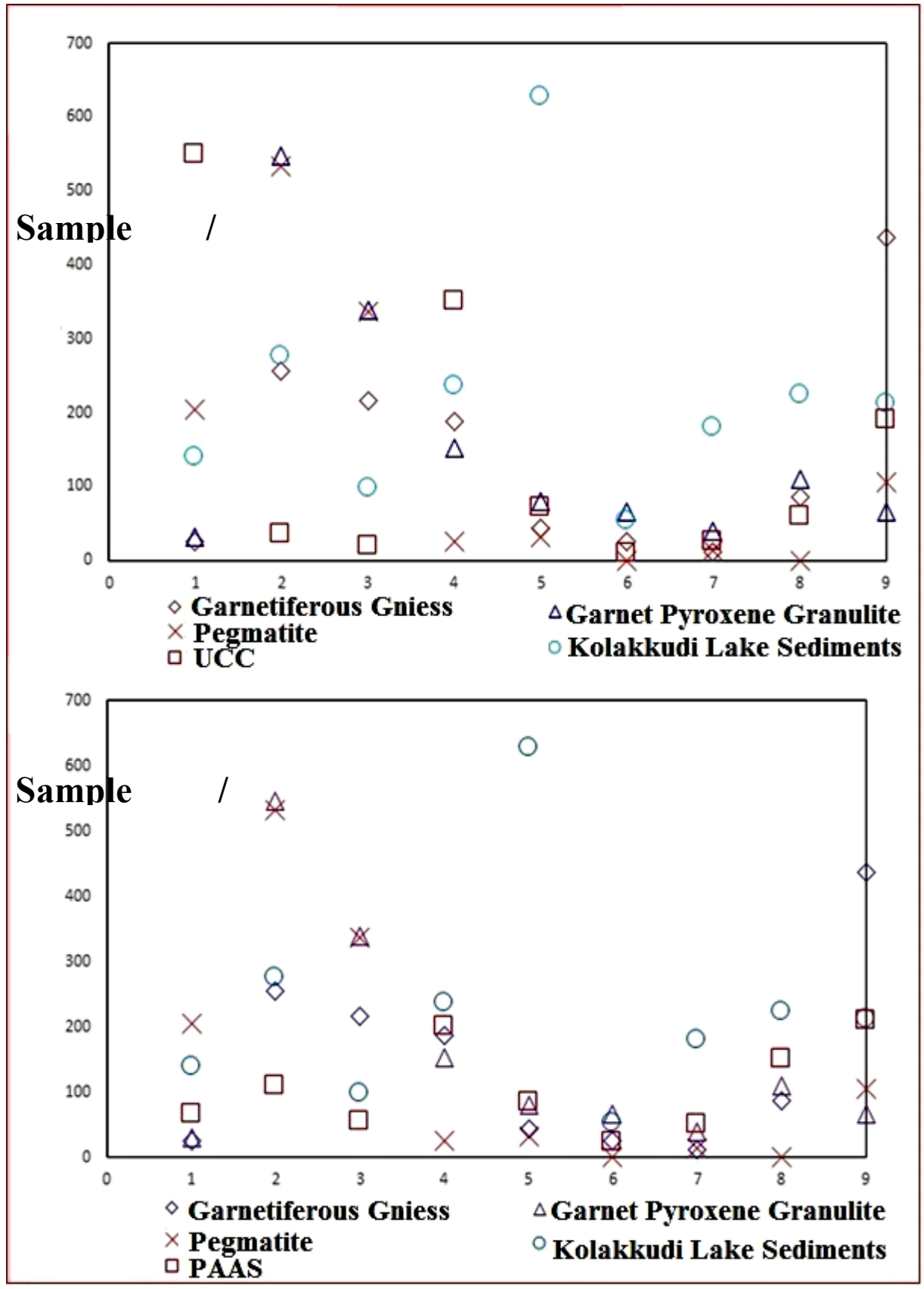

Fig. 5 Trace elemental variation for the source rock and Kolakkudi lake sediments. 

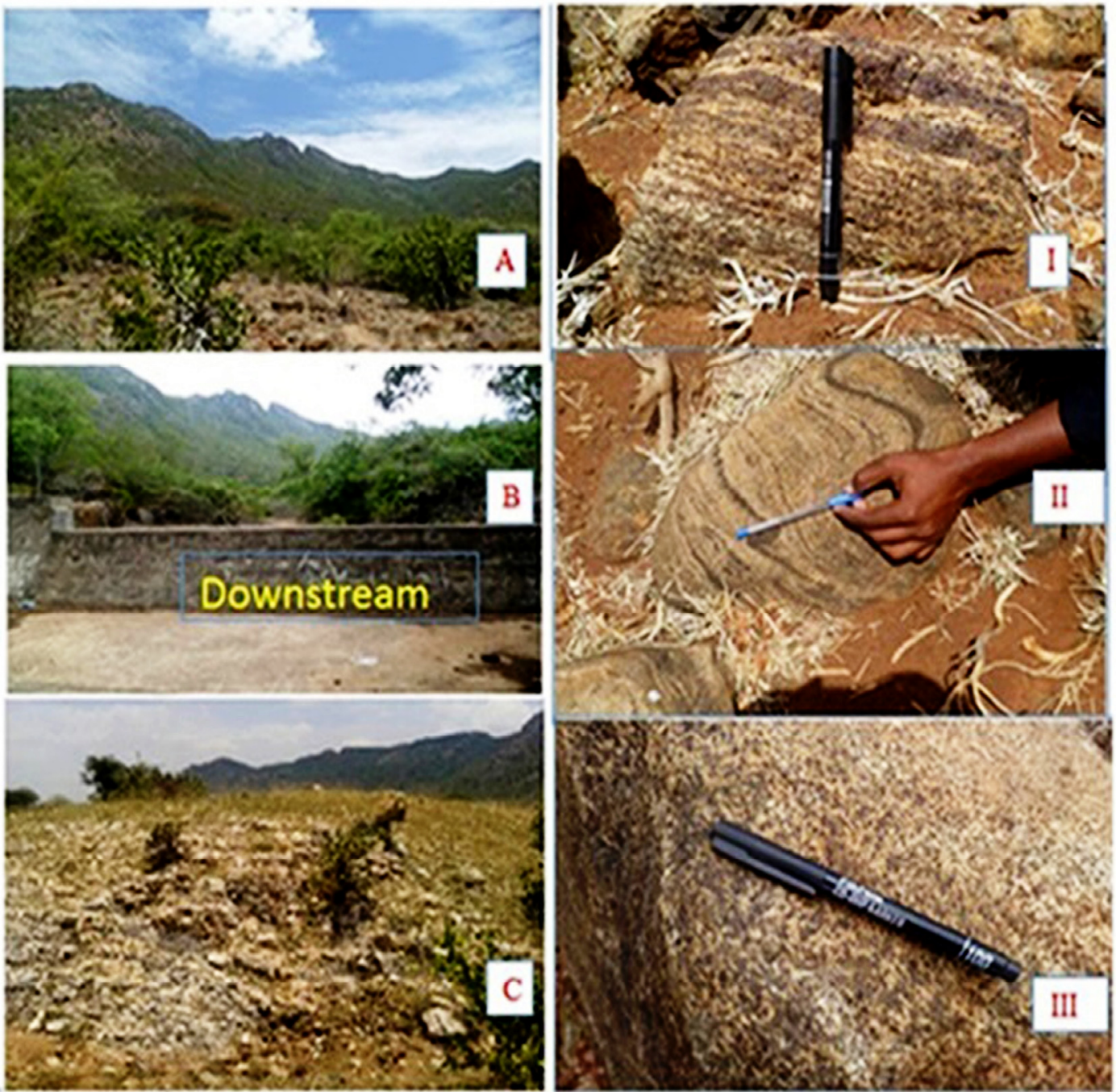

A - Panoramic view of Talamalai Hills

B - Down stream side of the Hills

$\mathrm{C}-$ Exposed Pegmatite rocks

I - Gernetiferous Gniess

II - Banded Magnetide Quartzite

III - Garnet Pyroxene Granulite

Fig. 6 Source rock Area (Talamalai Hills).

magnetite quartzite rocks (Fig. 5). The banded iron formations and associated rocks of the study area had undergone granulite facies of metamorphism (Bavinton et al., 1980). $\mathrm{Zn}$ is very abundance in lake sediments compared to PAAS its value very high due to concentrations of zinc mainly governed by the source rocks and weathering conditions of Kolakkudi lake area. Zinc is generally soluble under humid weathering conditions, but may be adsorbed on manganese or iron oxides and clays or organic matter. Concentrations of zinc in soils are mainly governed by the source rocks (Kiekens, 1995). Zirconium from small well-rounded zircons observed in some of the samples and the $\mathrm{Zr}$ content in the lake sediments and source rocks varies between 211 and $437 \mathrm{ppm}$ which is compared to value of PAAS (210 ppm). Sr and Ba value compared to lake sediments with UCC values due to the source of pegmatite rocks (Fig. 6). Strontium and Barium mostly reside in plagioclase and K-feldspar respectively (Puchelt, 1972; Bhat, 2017).
The variation of Cobalt is compared to lake sediments with PAAS and UCC which value is very high dependent on the texture of sediment and amount clay present. $\mathrm{Zn}$ is very high concentrations in lake sediments whereas sediments were widely spread source from Garnetiferous Gneiss and Garnet pyroxene granulite. Sediments formed from basic rocks are richer in $\mathrm{Zn}$, whereas sediments from granites, gneisses, etc., (Vinogradov, 1959). Ba rich in sediments, one of these samples with higher plagioclase $\mathrm{Ba}$ concentration, several of which are pegmatites from metasedimentary exposures in Talamalai hills (Fig. 6).

\section{Ce-ANOMALY}

The samples with negative $\mathrm{Ce}$ anomalies are also having lower $\mathrm{Ce}$ concentrations. Ce relative to its neighboring REEs generally indicates a negative Ceanomaly and this may be mainly from the presence of siliceous organisms. The Ce anomaly is calculated as Follows: 


$$
\text { Ce anomaly }=\frac{(\mathrm{Ce})}{\mathrm{Ce}^{*}}=\frac{(\mathrm{Ce}) \mathrm{n}}{\sqrt{(\mathrm{La}) \mathrm{n}(\mathrm{Pr}) \mathrm{n}}}
$$

The Ce anomalies of the studied area varies from 0.98 to $1.21 \mathrm{ppm}$ in core sediments. This value plotted on the Ce anomaly $\mathrm{Vs} \mathrm{Nd}$ concentration diagram (Fig. 6). Elderfield and Pagett (1986) set the Ce anomaly division as Oxic and anoxic conditions, whereas Wright et al. (1987) based on further evidence shifts this boundary tentatively to $-0.10 \mathrm{Ce}$ anomaly measured in carbonates can be used to help understand Palaeo-redox conditions. $\mathrm{Ce}$ anomaly denotes the terrigenous source as origin and displayed Oxic environment that prevails along the study region.

\section{CONCLUSIONS}

REE concentrations in Kolakkudi lake sediments range from $0.43 \mathrm{ppm}$ to $51.5 \mathrm{ppm}$, indicating a gradual increase towards the depth of sediment cores. The normalized pattern of $\mathrm{La} / \mathrm{Yb}$ ratio ranges (3.33 to $15.4 \mathrm{ppm}$ ) that relative depletion in HREEs. The concentrations of most individual REEs in samples showed good correlation with each other. The normalized pattern of core sediments shows no significant LREE enrichment and exhibit flat HREE pattern. The core sediments show high ratio of LREE / HREE (3.14 to $8.34 \mathrm{ppm}$ ) which indicates that these sediments were derived from the basic source rocks (Table 3). The clustering of core sediments in the $\mathrm{Th} / \mathrm{Co} \mathrm{Vs} \mathrm{La} / \mathrm{Sc}$ bivariate plot suggests a basic nature of the source rocks. PAAS-normalized REE patterns are in agreement with source sediment REE in respective cores. $\mathrm{Eu}$ anomaly is inherited from ore material and controlled by sediment constituents. The $\mathrm{Ce}$ anomaly $\mathrm{Vs} \mathrm{Nd}$ concentration bivariant plot for Kolakkudi Lake sediments fall in the field of slow sedimentation under Oxic condition and therefore, REE content in the sediments are not a consequence of anthropogenic activity. The positive correlation between $\mathrm{Th}$ and La suggests coherent behavior between REE (La) and $\mathrm{Th}$ and stronger grain size effect on sediments than that of provenance (Table 4). This implies that higher La resides in clays. Trace elemental studies of Kolakkudi lake sediments and its source rock result their high-grade metamorphic rocks. The strong association of $\mathrm{Cr}, \mathrm{Ni}, \mathrm{Zn}, \mathrm{Co}, \mathrm{Cu}$, $\mathrm{Pb}$, and $\mathrm{V}$ in sediments and high loading of these elements with clay content play a significant role in the distribution and sorption of these trace elements in sediments and the source rocks of lake sediments reveals that are metasedimentary origin.

\section{ACKNOWLEDGMENTS}

The present research was carried out within the framework of the Ph.D. thesis of the first author, Sivasamandy R. The author would like to thank the PG \& Research Department of Geology, National College, Trichy for providing the necessary equipment.

\section{REFERENCES}

Anaya-Gregorio, A., Armstrong-Altrin, J.S., MachainCastillo, M.L., Montiel-García, P.C. and RamosVázquez, M.A.: 2018, Textural and geochemical characteristics of late Pleistocene to Holocene finegrained deep-sea sediment cores (GM6 and GM7), recovered from southwestern Gulf of Mexico. J. Palaeogeog., 7, 3, 253-271.

DOI: $10.1186 / \mathrm{s} 42501-018-0005-3$

Armstrong-Altrin, J.S. and Machain-Castillo, M.L.: 2016, Mineralogy, geochemistry, and radiocarbon ages of deep-sea sediments from the Gulf of Mexico, Mexico. J. S. Am. Earth Sci., 71, 182-200.

DOI: 10.1016/j.jsames.2016.07.010

Armstrong-Altrin, J.S., Lee, Y.I., Kasper-Zubillaga, J.J. and Trejo-Ramírez, E.: 2017, Mineralogy and geochemistry of sands along the Manzanillo and El Carrizal beach areas, southern Mexico: implications for palaeoweathering, provenance, and tectonic setting. Geol. J., 52, 4, 559-582.

DOI: $10.1002 / \mathrm{gj} .2792$

Armstrong-Altrin, J.S., Ramos-Vázquez, M.A., ZavalaLeón, A.C. and Montiel-García, P.C.: 2018, Provenance discrimination between Atasta and Alvarado beach sands, western Gulf of Mexico, Mexico: Constraints from detrital zircon chemistry and U-Pb geochronology. Geol. J., 53, 6, 2824-2848. DOI: $10.1002 /$ gj.3122

Awwiller, D.N.: 1993, Illite /smectite formation and potassium mass transfer during burial diagenesis of mudrocks: A study from the Texas Gulf Coast Paleocene-Eocene. J. Sed. Petrol., 63, 501-512.

DOI: 10.1306/D4267B3B-2B26-11D7-8648000102C1865D

Bavinton, O.A. and Taylor, S.R.: 1980, Rare-Earth element geochemistry of Archean metasedimentary rocks from Kambalda, Western-Australia. Geochim. Cosmochim. Ac., 44, 639-648. DOI: $10.1016 / 0016-7037(80) 90154-4$

Bhat, N.A.: 2017, Geochemistry of surface water and stream sediments in Karewa basin of South Kashmir, India: Implications on human health, agriculture and environmental studies. PhD Thesis; submitted to Banarus Hindu University.

Bhatia, M.R. and Crook, K.A.W.: 1986, Trace elements characteristics of greywackes and tectonic setting discrimination of sedimentary basins. Contrib. Mineral. Petr., 92, 181-193. DOI: $10.1007 / \mathrm{BF} 00375292$

Caetano, M., Prego, R., Vale, C., de Pablo, H. and Marmolejo-Rodríguez, J.: 2009, Record of diagenesis of rare earth elements and other metals in a transitional sedimentary environment. Mar. Chem., 116, 36-46. DOI:10.1016/j.marchem.2009.09.003

Chen, L.M., Zhang, G.L. and Jin, Z.D.: 2014, Rare earth elements of a 1000-year paddy soil chronosequence: Implications for sediment provenances. Parent material uniformity and pedological changes. Geoderma, 230, 274-279. DOI: 10.1016/j.geoderma.2014.03.023

Cullers, R.J., Basu, A. and Suttner, L.J. : 1988, Geochemical signature of provenance in sand-size material in soils and stream sediments near the Tobacco Root Batholith, Montana, U.S.A. Chem. Geol., 70, 335348. DOI: 10.1016/0009-2541(88)90123-4

Cullers, R.L. and Podkovyrov, V.M.: 2002, The source and origin of terrigenous sedimentary rocks in the 
Table 3 REE concentration and ratios in core sediments of Kolakkudi Lake.

\begin{tabular}{|c|c|c|c|c|c|c|c|c|c|c|c|c|}
\hline S.No & $\begin{array}{c}\text { Sampling } \\
\text { stations }\end{array}$ & $\begin{array}{l}\text { Range of } \\
\text { Depth } \\
\text { (in cm) }\end{array}$ & LREE & HREE & LREE/HREE & SREE & $\mathbf{L a} / \mathbf{C o}$ & $\mathbf{L a} / \mathbf{S c}$ & Th/Sc & $\mathrm{Cr} / \mathrm{Th}$ & $\mathbf{L a} / \mathbf{S m}$ & $\mathbf{G d} / \mathbf{Y b}$ \\
\hline 1 & KLKD-1 & $90-120$ & 132.4 & 24.2 & 5.47 & 156.6 & 0.68 & 0.87 & 0.08 & 85.3 & 4.88 & 1.79 \\
\hline 2 & KLKD-2 & $60-90$ & 67.0 & 17.5 & 3.82 & 84.5 & 0.33 & 0.49 & 0.03 & 231.3 & 3.53 & 1.51 \\
\hline 3 & KLKD-3 & $60-90$ & 146.6 & 34.7 & 4.22 & 181.3 & 0.93 & 0.92 & 0.20 & 25.3 & 3.08 & 1.51 \\
\hline 4 & KLKD-4 & $120-150$ & 78.6 & 22.6 & 3.47 & 101.3 & 0.36 & 0.54 & 0.07 & 109.7 & 4.17 & 1.35 \\
\hline 5 & KLKD-5 & $30-60$ & 374.7 & 50.2 & 7.46 & 425.0 & 2.15 & 2.23 & 0.14 & 35.3 & 6.30 & 2.33 \\
\hline 6 & \multirow{2}{*}{ KLKD-6 } & $30-60$ & 76.5 & 22.3 & 3.42 & 98.8 & 0.29 & 0.46 & 0.05 & 156.6 & 3.84 & 1.36 \\
\hline 7 & & $240-270$ & 101.7 & 24.8 & 4.10 & 126.5 & 0.46 & 0.63 & 0.04 & 191.2 & 4.17 & 1.50 \\
\hline 8 & KLKD-7 & $30-60$ & 67.2 & 23.0 & 2.93 & 90.2 & 0.25 & 0.37 & 0.04 & 201.2 & 3.29 & 1.25 \\
\hline 9 & KLKD-8 & $60-90$ & 82.4 & 21.3 & 3.86 & 103.7 & 0.36 & 0.53 & 0.04 & 195.2 & 4.47 & 1.39 \\
\hline 10 & \multirow{2}{*}{ KLKD-9 } & $60-90$ & 261.4 & 31.3 & 8.34 & 292.7 & 1.26 & 1.60 & 0.11 & 53.2 & 7.05 & 2.16 \\
\hline 11 & & $90-120$ & 213.4 & 31.3 & 6.81 & 244.7 & 0.95 & 1.23 & 0.05 & 129.0 & 6.73 & 1.63 \\
\hline 12 & KLKD-10 & $90-120$ & 202.1 & 34.0 & 5.94 & 236.2 & 0.92 & 1.27 & 0.08 & 84.9 & 6.40 & 1.46 \\
\hline 13 & \multirow{3}{*}{ KLKD-11 } & $30-60$ & 75.8 & 22.9 & 3.31 & 98.7 & 0.31 & 0.46 & 0.03 & 244.1 & 4.09 & 1.24 \\
\hline 14 & & $90-120$ & 87.1 & 25.6 & 3.41 & 112.7 & 0.35 & 0.49 & 0.03 & 229.0 & 4.53 & 1.21 \\
\hline 15 & & $150-180$ & 60.8 & 23.5 & 2.59 & 84.3 & 0.21 & 0.32 & 0.03 & 275.4 & 3.03 & 1.23 \\
\hline 16 & \multirow{8}{*}{ KLKD-12 } & $30-60$ & 54.9 & 20.0 & 2.74 & 74.9 & 0.23 & 0.33 & 0.03 & 272.2 & 3.04 & 1.21 \\
\hline 17 & & $90-120$ & 67.3 & 22.9 & 2.94 & 90.3 & 0.28 & 0.41 & 0.04 & 203.0 & 3.91 & 1.19 \\
\hline 18 & & $150-180$ & 68.8 & 22.5 & 3.05 & 91.3 & 0.27 & 0.39 & 0.03 & 277.9 & 3.73 & 1.24 \\
\hline 19 & & $210-240$ & 61.9 & 22.8 & 2.71 & 84.7 & 0.24 & 0.34 & 0.05 & 170.7 & 3.33 & 1.19 \\
\hline \multirow[t]{4}{*}{20} & & $240-270$ & 76.5 & 24.3 & 3.14 & 100.8 & 0.28 & 0.42 & 0.05 & 169.6 & 3.64 & 1.29 \\
\hline & & Min. & 54.9 & 17.5 & 2.59 & 74.9 & 0.21 & 0.32 & 0.03 & 25.3 & 3.03 & 1.19 \\
\hline & & Max. & 374.7 & 50.2 & 8.34 & 425.0 & 2.15 & 2.23 & 0.20 & 277.9 & 7.05 & 2.33 \\
\hline & & Mean. & 117.9 & 26.1 & 4.19 & 144.0 & 0.56 & 0.71 & 0.06 & 167.0 & 4.36 & 1.45 \\
\hline
\end{tabular}


Table 4 Grain size data of Kolakkudi Lake Sediments.

\begin{tabular}{|c|c|c|c|c|c|c|c|c|c|}
\hline & & $\mathbf{M z}$ & Verbal limit & $(\sigma 1)$ & Verbal limit & (Sk) & Verbal limit & $\left(\mathbf{K}_{\mathrm{G}}\right)$ & Verbal limit \\
\hline KLKD-1 & $90-120$ & 1.6519 & Medium grained & 1.0525 & Poorly sorted & -0.0339 & Symmetrical & 0.7337 & Platykurtic \\
\hline KLKD-2 & $60-90$ & 2.1204 & Fine grained & 0.8815 & Moderately sorted & -0.3917 & Very coarse Skewed & 1.3229 & Leptokurtic \\
\hline KLKD-3 & $60-90$ & 0.9550 & Coarse grained & 0.7555 & Moderately sorted & 0.6641 & Very Fine Skewed & 0.7740 & Platykurtic \\
\hline KLKD-4 & $120-150$ & 1.5437 & Medium grained & 0.9524 & Moderately sorted & -0.0448 & Symmetrical & 0.6727 & Platykurtic \\
\hline KLKD-5 & $30-60$ & 1.2234 & Medium grained & 0.9530 & Moderately sorted & 0.5662 & Very Fine Skewed & 0.7130 & Platykurtic \\
\hline \multirow{2}{*}{ KLKD-6 } & $30-60$ & 1.3592 & Medium grained & 0.8556 & Moderately sorted & 0.0692 & Symmetrical & 0.7274 & Platykurtic \\
\hline & $240-270$ & 1.4878 & Medium grained & 0.7591 & Moderately sorted & -0.1552 & Coarse skewed & 1.0118 & Mesokurtic \\
\hline KLKD-7 & $30-60$ & 1.2057 & Medium grained & 0.7381 & Moderately sorted & 0.1264 & Fine skewed & 0.7583 & Platykurtic \\
\hline KLKD-8 & $60-90$ & 1.7243 & Medium grained & 0.9234 & Moderately sorted & -0.1417 & Coarse skewed & 0.8502 & Platykurtic \\
\hline \multirow{2}{*}{ KLKD-9 } & $60-90$ & 2.2297 & Fine grained & 0.9737 & Moderately sorted & -0.3444 & Very Fine Skewed & 1.1178 & Leptokurtic \\
\hline & $90-120$ & 1.7344 & Medium grained & 1.0783 & Poorely sorted & -0.1048 & Coarse skewed & 0.6528 & Very platykurtic \\
\hline KLKD-10 & $90-120$ & 1.3456 & Medium grained & 0.9465 & Moderately sorted & -0.1615 & Coarse symmetrical & 0.6199 & Very platykurtic \\
\hline \multirow{3}{*}{ KLKD-11 } & $30-60$ & 2.4116 & Fine grained & 0.7846 & Moderately well sorted & -0.0820 & Symmetrical & 1.1077 & Mesokurtic \\
\hline & $90-120$ & 2.4739 & Fine grained & 0.6756 & Moderately well sorted & -0.0798 & Symmetrical & 0.8584 & Platykurtic \\
\hline & $150-180$ & 2.4330 & Medium grained & 0.6208 & Moderately sorted & -0.1615 & Coarse skewed & 0.6199 & Very platykurtic \\
\hline \multirow{5}{*}{ KLKD-12 } & $30-60$ & 1.9998 & Medium grained & 0.6253 & Moderately well sorted & 0.1268 & Fine skewed & 1.1012 & Mesokurtic \\
\hline & $90-120$ & 2.1548 & Fine grained & 0.6010 & Moderately well sorted & 0.3458 & Very fine skewed & 1.2414 & Leptokurtic \\
\hline & $150-180$ & 2.2073 & Fine grained & 0.5111 & Moderately well sorted & 0.1842 & Fine skewed & 1.0040 & Mesokurtic \\
\hline & $210-240$ & 2.2590 & Fine grained & 0.5433 & Moderately well sorted & 0.1530 & Fine skewed & 0.9707 & Mesokurtic \\
\hline & $240-270$ & 2.2665 & Fine grained & 0.5254 & Moderately well sorted & 0.0535 & Symmetrical & 0.9791 & Mesokurtic \\
\hline
\end{tabular}


Mesoproterozoic Ui group, southeastern Russia. Precambrian Res., 117, 157-183.

DOI: 10.1016/S0301-9268(02)00079-7

Das, B.K., AL-Mikhlafib, A.S. and Kaura, P.: 2006, Geochemistry of Mansar Lake sediments, Jammu, India: Implication for source-area weathering, provenance, and tectonic setting, J. Asian Earth Sci., 26, 6, 649-668. DOI: 10.1016/j.jseaes.2005.01.005

Das, B.K. and Haake, B.: 2003, Geochemistry of Rewalsar Lake sediment, Lesser Himalaya, India: implications for source-area weathering, provenance and tectonic setting. Geosci. J., 7, 299-312. DOI: $10.1007 / \mathrm{BF} 02919560$

Das, B.K.: 2002, Biogeochemistry as an indicator of organic matter sources, paleolimnological and paleoenvironmental change in lacustrine sediments: a study of two Himalayan lakes. Environ. Geosci. 9, 115-126. DOI:10.1046/j.1526-0984.2002.93005.x

Elderfield, H. and Pagett, R.: 1986, Rare earth elements in ichthyoliths: Variations with redox conditions and depositional environment. Sci. Total Environ., 49, 175-197. DOI: 10.1016/0048-9697(86)90239-1

Elderfield, H., Upstill Goddard, R. and Sholkovitz, E.R.: 1990, The rare earth elements in rivers, estuaries, and coastal seas and their significance to the composition of ocean waters. Geochim. Cosmochim. Ac., 54, 971991. DOI: 10.1016/0016-7037(90)90432-K

Frost, C.D. and Winston, D.: 1987, Nd isotope systematics of coarse and fine-grained sediments: Examples from the Middle Proterozoic Belt-Purcell Super group. J. Geol., 95, 309-327. DOI: 10.1086/629132

Gallet, S., John, B.M. and Toril, M.: 1996, Geochemical characterization of the Luochuan loess-paleosol sequence, China, and paleoclimatic implications. Chem. Geol., 133, 1-4, 67-88.

DOI: $10.1016 / \mathrm{S} 0009-2541(96) 00070-8$

Gromet, L.P., Dymek, R.F, Haskin, L.A. and Korotev, R.L.:1984, The 'C: its compilation, major and trace element characteristics. Geochim. Cosmochim. Ac., 48, 2469-2482. DOI: 10.1016/0016-7037(84)90298-9

Haskin, L.A., Wildeman, T.R., Frey, F.A., Collins, K.A., Keedy, C.R. and Haskin, M.A.: 1966, Rare earths in sediments, J. Geophys. Res., 71, 24, 6091-6105. DOI: 10.1029/JZ071i024p06091

Henderson, P.: 1984, Rare Earth Element Geochemistry. Elsevier (Ed.), Amsterdam, 510 pp.

Hernández-Hinojosa, V., Montiel-García, P.C., ArmstrongAltrin, J.S., Nagarajan, R. and Kasper-Zubillaga, J.J.: 2018, Textural and geochemical characteristics of beach sands along the western Gulf of Mexico, Mexico. Carpath. J. Earth Environ. Sci., 13, 1, 161174. DOI: $10.26471 /$ cjees $/ 2018 / 013 / 015$

Jin, Z.D., Wang, S., Shen, J. and Wang, Y.: 2003, Carbonate versus silicate $\mathrm{Sr}$ isotope in lake sediments and its response to the Little Ice Age. Chin. Sci. Bull. 48, 95100. DOI: $10.1360 / 03$ tb 9020

Jin, Z.D., Wang, S., Shen, J., Zhang, E., Ji, J., Li, F. and Lu, X.: 2001, Chemical weathering since the Little Ice Age recorded in lake sediments: a high-resolution proxy of past climate. Earth Surf. Proc. Land., 26, 775-782. DOI: 10.1002/esp.224

Kasanzu, C., Maboko, M.A.H. and Manya, S.: 2008, Geochemistry of fine-grained clastic sedimentary rocks of the Neoproterozoic Ikorongo Group, NE Tanzania: Implications for provenance and source rock weathering. Precambrian Res., 164, 201-213. DOI: 10.1016/j.precamres.2008.04.007

Keikens, L.: 1995, Zinc: in Alloway, B.J., ed.: Heavy Metals in Soils, Blackie Academic and Professional, Glasgow, United Kingdom, 11-37.

Lee, S, Moon, J.I.W. and Moon, H.S.: 2003, Heavy metals in the bed and suspended sediments of Anyang River, Korea: implications for water quality. Environ. Geochem. Health, 25, 433-452. DOI: 10.1023/B:EGAH.0000004567.80084.d1

McLennan, S.M. and Taylor, S.R.: 1991, Sedimentary-rocks and crustal evolution: Tectonic setting and secular trends. J. Geol., 99, 1-21. DOI: 10.1086/629470

McLennan, S.M., Nance, W.B. and Taylor, S.R.:1980, Rare earth element- thorium correlations in sedimentary rocks, and the composition of the continental crust. Geochim. Cosmochim. Ac., 44, 1833-1839. DOI: 10.1016/0016-7037(80)90232-X

Morgan, B., Rate, A.W., Burton, E.D., and Smirk, M.: 2012, Enrichment and fractionation of rare earth elements in FeSand organic-rich estuarine sediments receiving acid sulfate soil drainage. Chem. Geol., 308, 60-73. DOI: 10.1016/j.chemgeo.2012.03.012

Munksgaard, N.C., Lim, K. and Parry, D.L.: 2003, Rare earth elements as provenance indicators in Norh Australian estuarine and coastal marine sediments. Estuar. Coast. Shelf Sci., 57, 399-409. DOI: $10.1016 / \mathrm{S} 0272-7714(02) 00368-2$

Nagarajan, R, Armstrong-Altrin, J.S, Nagendra, R, Madhavaraju, J. and Moutte, J.: 2007b, Petrography and geochemistry of terrigenous sedimentary rocks in the Neoproterozoic Rabanpalli Formation, Bhima basin, southern India: Implications for paleoweathering condition, provenance, and source rock composition. J. Geol. Soc. India, 70, 2, 297-312.

Nagarajan, R, Madhavaraju, J, Nagendra, R, ArmstrongAltrin, J.S. and Moutte, J.: 2007a, Geochemistry of Neoproterozoic shales of the Rabanpalli Formation, Bhima basin, Northern Karnataka, southern India: Implications for provenance and paleoredox conditions. Rev. Mex. Cienc. Geol., 24, 150-160.

Puchelt, H.: 1972, Barium. In: Handbook of Geochemistry (Wedepohl, K.H. et al., eds.), 56B1-56O2, Berlin.

Ramos-Vázquez, M.A., Armstrong-Altrin, J.S., MachainCastillo, M.L. and Gío-Argáez, F.R.: 2018, Foraminiferal assemblages, $14 \mathrm{C}$ ages, and compositional variations in two sediment cores in the western Gulf of Mexico. J. S. Am. Earth Sci., 88, 480 496. DOI: 10.1016/j.jsames.2018.08.025

Rose, N.L., Boyle, J.F., Du, Y., Yi, C., Dai, X., Appleby, P.G., Bennion, H., Cai, S. and Yu, L.: 2004, Sedimentary evidence for changes in the pollution status of Taihu in the Jiangsu region of eastern China. J. Paleolimnol., 32, 41-51. DOI: 10.1023/B:JOPL.0000025282.06961.42

Sadeghi, M., Morris, G.A., Carranza, E.J.M., Ladenberger, A. and Andersson, M.: 2013, Rare earth element distribution and mineralization in Sweden: An application of principal component analysis to FOREGS soil geochemistry. J. Geochem. Explor., 133, 160-175. DOI: 10.1016/j.gexplo.2012.10.015

Santos, I.R., Fávaro, D.I.T., Schaefer, C.E.G.R. and SilvaFilho, E.V.: 2007, Sediment geochemistry in coastal maritime Antarctica (Admiralty Bay, King George 
Island): Evidence from rare earths and other elements. Mar. Chem., 107, 464-474.

DOI:10.1016/j.marchem.2007.09.006

Silva, Y.J.A.B., Nascimento, C.W.A., Biondi, C.M., Van Straaten, P., Souza, V.S., Silva, Y.J.A.B., et al.: 2017a, Influence of metaluminous granite mineralogy on the rare earth element geochemistry of rocks and soils along a climosequence in Brazil. Geoderma, 306, 28-39. DOI: 10.1016/j.geoderma.2017.06.031

Suguio, K.:1973, Introduçao a sedimentologia. Edgard Blucher, Sao Paulo, 317 pp.

Tanaka, K., Akagawa, F., Yamamoto, K., Tani, Y., Kawabe, T. and Kawai, T.: 2007, Rare earth element geochemistry of Lake Baikal sediment: its implication for geochemical response to climate change during the Last Glacial/Interglacial transition. Quaternary Sci. Rev., 26, 1362-1368.

DOI: 10.1016/j.quascirev.2007.02.004

Tapia-Fernandez, H.J., Armstrong-Altrin, J.S. and Selvaraj, K.: 2017, Geochemistry and U-Pb geochronology of detrital zircons in the Brujas beach sands, Campeche, Southwestern Gulf of Mexico, Mexico. J. S. Am. Earth Sci., 76, 346-361.

DOI: 10.1016/j.jsames.2017.04.003

Taylor, S.R. and McLennan, S.M.: 1985, The continental crust: Its composition and evolution: An examination of the geochemical record preserved in sedimentary rocks. Blackwell Science, Oxford, 312.

Tripathi, J.K. and Rajamani, V.: 1999, Geochemistry of the loessic sediments on Delhi ridge, eastern Thar Desert, Rajasthan: implication for exogenic processes. Chem. Geol., 155, 265-278.

DOI: $10.1016 / \mathrm{S} 0009-2541(98) 00168-5$

Tyler, G.: 2004, Rare earth elements in soil and plant systems-a review. Plant Soil, 267, 1-2, 191-206. DOI: $10.1007 / \mathrm{s} 11104-005-4888-2$
Vinogradov, A.P.: 1959, The geochemistry of rare and dispersed chemical elements in soils. Second ed., Consultants Bureau Inc., New York.

Wang, L., and Liang, T.: 2016, Anomalous abundance and redistribution patterns of rare earth elements in soils of a mining area in inner Mongolia, China. Environ. Sci. Pollut. R., 23, 11330-11338. DOI: $10.1007 / \mathrm{s} 11356-016-6351-8$

Wright, J., Schrader, H. and Holser, W.: 1987, Paleoredox variations in ancient oceans recorded by rare earth elements in fossil apatite. Geochim. Cosmochim. Ac., 51, 631-644. DOI: 10.1016/0016-7037(87)90075-5

Yamamoto, K., Yamashita, F. and Adachi, M.: 2005, Precise determination of REE for sedimentary rocks issued by the Geological Survey of Japan. Geochem. J., 39, 289-297. DOI: 10.2343/geochemj.39.289

Yang, ZR, Graham, E.Y. and Luons, W.B.: 2003, Geochemistry of Pyramid Lake sediments: Influence of anthropogenic activities and climatic variations within the basin. Environ. Geol., 43, 688-97. DOI: $10.1007 / \mathrm{s} 00254-002-0691-\mathrm{z}$ 